\title{
PEMAKAIAN BAHASA INDONESIA RAGAM LISAN OLEH PENGAJAR MADRASAH ALIYAH KOTA PEKANBARU
}

\author{
(The Use Of Indonesian Variety Of Oral By Madrasah Aliyah Teachers, Pekanbaru City)
}

\author{
Oleh: Nursalim*, dan Musa Thahir \\ E-mail: nursalim@uin-suska.ac.id
}

*) Fakultas Tarbiyah dan Keguruan, UIN Sultan Syarif Kasim Riau

\begin{abstract}
This study seeks to reveal the implementation of the Outlines of the Teaching Program (GBPP) for Indonesian Language Subjects, the 1994 Curriculum, Junior High School (SLTP) in teaching and learning activities (KBM) in the classroom. The objectives of this study were to: (1) determine whether the teacher met "reasonable" teaching procedures, (2) plan and implement classroom teaching according to the allocated time, and (3) use the method appropriately. The results of classroom observations and interviews with 18 junior high school second grade Indonesian teachers in various regions indicate that the time allocation provided in the Indonesian language GBPP is considered adequate, however, some teachers have not used this time efficiently and effectively. Teachers generally do not have good skills in planning and implementing teaching and learning activities. The textbook is relied on as a reference for teaching rather than a reference for the planning they are supposed to compile. The purpose of teaching language so that students are able to read, listen, write and listen has not received proportional attention.
\end{abstract}

Key words: Curriculum, study time, teaching and learning activities, teacher performance, planning, teaching implementation

\section{PENDAHULUAN}

Setiap bahasa di dunia ini memiliki berbagai ragam. Ragam bahasa merupakan variasi bahasa yang terjadi karena pemakaian Bahasa (Darwin, et.al., 2018). Munculnya keragaman bahasa ini bukan hanya disebabkan oleh para penuturnya yang tidak homogen, melainkan keragaman interaksi sosial yang mereka lakukan. Keragaman ini semakin bertambah jika bahasa tersebut dipakai oleh penutur yang sangat banyak serta dalam wilayah yang sangat luas (Setiawati, 2019). Bahasa Indonesia yang sangat luas wilayah pemakainya dan bermacam ragam penuturnya, mau tidak mau, takluk pada hukum perubahan. Ragam bahasa menurut pendidikan formal, yang bersilang dengan ragam dialek, menunjukkan perbedaan yang jelas antara kaum yang berpendidikan formal dan tidak formal.
Dalam Pendidikan formal, seorang guru juga harus mengetahui perkembangan, pembinaan, dan pembakuan bahasa Indonesia. Penggunaan bahasa Indonesia bagi seorang guru tidak hanya terbatas dalam ruang resmi tetapi juga di luar lingkungan sekolah bahkan di dalam lingkungan masyarakat yang lebih luas. Seorang guru haruslah menggunakan bahasa yang baik dan benar, karena apapun yang dikatakan oleh guru akan ditiru oleh anak didik (Tarmizi, 2016). Anak usia dini sangat cepat menyerap bahasa pada saat di lingkungan sekolah ketika guru berinteraksi di dalam kelas guru harus menggunakan bahasa yang baik dan benar (Filtri \& Efastri, 2016). Jadi, seorang guru harus mampu menguasai bahasa.

Pemakaian bahasa Indonesia di masyarakat sering dipengaruhi oleh 
bahasa lain yang dikuasai oleh masyarakat penuturnya. Demikian pula halnya masyarakat Madrasah Aliyah khususnya Madrasah Aliyah di Kota Pekanbaru, pemakaian bahasanyapun dipengaruhi oleh bahasa lain yang dikuasainya seperti bahasa Inggris dan bahasa Arab. Hal ini disebabkan karena pengajar Madrasah Aliyah telah mempelajari kedua bahasa tersebut. Di samping itu, bahasa Arab merupakan sumber utama dalam mengali ilmu keagamaan (Islam) yang merupakan ciri khas keilmuan pengajar di Madrasah Aliyah. Kemampuan menguasai lebih dari dua bahasa oleh pengajar tersebut menyebabkan pengajar dapat dikategorikan sebagai seorang multibahasa.

Berdasarkan uraian di atas, dapat dikatakan bahwa penggunaan bahasa tidaklah seragam, melainkan beragam. Bahasa Indonesia yang digunakan oleh petani, tentu berbeda dengan bahasa yang oleh pedagang atau profesi lainnya. Demikian halnya bahasa yang digunakan oleh pengajar tentu berbeda dengan bahasa yang digunakan oleh golongan masyarakat lainnya (Devianty, 2017); (Suhendar, 2016). Dalam dunia pendidikan, kemampuan berbahasa merupakan titik sentral pengajaran. Kemampuan berbahasa merupakan tujuan utama pelaksanaan pengajaran bahasa Indonesia, baik pada tingkat dasar, menengah, maupun tingkat tinggi. Bahasa pengajar Madrasah Aliyah menarik untuk dikaji, karena bahasa mereka pada umumnya dipengaruhi oleh bahasa keagamaan. Pengaruh tersebut dapat terjadi dari segi pelafalan, bentuk kata, pilihan kata, dan ragam kalimat. Di samping itu, sebagai pengajar/pengasuh, mereka memiliki peranan yang sangat besar dalam mempengaruhi bahasa yang akan digunakan santrinya kelak. Bahasa pengajar sering dijadikan model oleh para siswanya dalam berkomunikasi.

Berdasarkan hasil penelusuran peneliti, ditemukan beberapa penelitian yang relevan terkait penelitian yang hendak peneliti lakukan, antara lain: 1) Penelitian oleh Wa Mirna (2020) tentang Karakteristik Bahasa Guru Dalam Interaksi Belajar Mengajar Bahasa Indonesia di Kelas XII MIPA 2 SMAN 1 Bangil Kabupaten Pasuruan. Hasil penelitian menunjukkan adanya karakteristik bahasa guru pada tuturan guru saat kegiatan pembelajaran. Repetisi terdapat dalam tuturan guru di SMAN 1 Bangil di kelas XII MIPA 2 saat menjelaskan, bertanya, memerintah dan menguatkan; 2) Penelitian oleh Wardhani, et.al (2019) tentang Penggunaan Ragam Bahasa Melalui Whatsapp Kalangan Mahasiswa Pascasarjana Pendidikan Bahasa dan Sastra Indonesia Universitas Halu Oleo (Suatu Kajian Sosiolinguistik). Hasil penelitian menunjukkan bahwa penggunaan ragam bahasa melalui obrolan WhatsApp grup kalangan mahasiswa Pascasarjana Pendidikan Bahasa dan Sastra Indonesia kelas B angkatan 2016 Universitas Halu Oleo meliputi penggunaan pemendekan kata, jargon dalam bahasa Indonesia, jargon dalam bahasa Ingris, jargon berbentuk singkatan dan jargon berbentuk akronim

Dalam penelitian ini, penulis akan menkaji pemakaian bahasa ragam lisan para pengajar Madrasah Aliyah di Kota Pekanbaru, yang dikaitkan dengan tiga aspek, yaitu situasi, isi, dan fungsi pembicaraan. Pada lingkup situasi pembicaraan, peneliti hanya menitikberatkan pada pemakaian bahasa ragam lisan dalam situasi formal, yaitu ketika pengajar mengajar di depan kelas. Pada lingkup isi, penelitian ini hanya difokuskan pada topic-topik pembicaraan yang terdapat dalam bahasa lisan pengajar. Pada hanya menfokuskan pada tujuan atau maksud penggunaan ragam bahasa pengajar. Dipilih bahasa ragam lisan pengajar Madrasah Aliyah sebagai objek penelitian, karena pengajar Madrasah Aliyah memiliki ragam bahasa yang berbeda dengan ragam pengajar 
lainnya.

Sasaran studi diprioritaskan pada pemakaian bahasa Indonesia ragam lisan oleh guru-guru Madrasah Aliyah Kota Pekanbaru. Bahasa lisan yang diteliti dalam penelitian ini adalah bahasa lisan lisan yang digunakan guru, sewaktu mengajar di kelas. Ragam lisan yang dipilih dengan pertimbangan bahwa ragam merupakan bagian penting untuk contoh kemampuan dasar berbahasa lisan dan berpikir nalar, sebagai basis tujuan pendidikan. Studi ini juga diarahkan untuk melihat/menelaah situasi kebahasaan yang terjadi di kelas dan di luar kelas, yaitu pemakaian bahasa Indonesia antara guru dengan guru, antara guru dengan siswa, dan antara guru dengan kelompok masyarakat lainnya.

\section{METODE PENELITIAN}

Penelitian ini dilakukan di 4 (empat) sekolah, yakni MAN 1, MAN 2 (Model), MA Hasanah, dan MA Ma'arif NU Riau. Setiap madrasah diambil $10 \%$ guru sebagai sampel dengan komposisi masing-masing madrasah sebagai madrasah negeri baik dan kurang, dan dua madrasah swasta baik dan kurang. Penentuan kategori sekolah sampel tersebut dilakukan secara purposif melalui konsultasi dengan pihak Kamenag kota Pekanbaru, dengan mempertimbangkan aspek peringkat pencapaian NEM tahun terakhir. Dengan cara ini madrasah sampel seluruhnya berjumlah 4 Madrasah, terdiri atas 2 Madrasah Negeri dan 2 Madrasah Swasta. Dalam studi ini kelas yang dijadikan sasaran observasi adalah guru Madrasah Aliyah Kota Pekanbaru. Dasar pemikirannya adalah guru tersebut merupakan guru yang mengajar dengan dibekali ilmu keabahasaan bahasa Indonesia, Inggris, dan sebagian bahasa Arab, yakni guru yang telah memiliki kemampuan tiga bahasa atau lebih dan secara khusus telah memiliki kemampuan berbicara yang baik. Dengan kata lain guru-guru madrasah Aliyah Kota
Pekanbaru telah memiliki kemampuan berbahasa yang memadai sesuai dengan syarat seorang guru. Responden yang menjadi sumber data dalam studi ini adalah kepala sekolah, guru Bahasa Indonesia, serta siswa yang diajar guru yang bersangkutan.

Data dikumpulkan dengan menggunakan instrumen pedoman wawancara, perekaman bahasa, dan pedoman observasi kelas. Observasi KBM untuk mata pelajaran Bahasa Indonesia ini hanya dilakukan pada kelas II (jika kelas pararel, dipilih secara acak) untuk dua jam pelajaran. Penggalian terhadap implementasi materi kurikulum juga hanya dibatasi pada pokok/sub pokok bahasan yang diajarkan selama 2 jam pelajaran tersebut, didukung dengan studi dokumentasi. Hasil analisis dan kesimpulan studi ini tidak dipretensikan untuk menggeneralisasikan KBM guru Bahasa Indonesia pada umumnya, melainkan terbatas pada diskripsi terhadap 18 sekolah sampel yang memiliki tipologi tertentu, yakni sekolah yang berada di daerah perkotaan, dan dengan kriteria mutu NEM. Informasi studi ini dapat digunakan sebagai cermin bagi KBM Bahasa Indonesia di sekolah lain yang memiliki tipologi yang mirip atau sama. Hasil pengumpulan data kemudian dianalisis menggunakan analisis deskriptif kuantitatif dengan bantuan SPSS versi 18.00 for Windows.

\section{HASIL DAN PEMBAHASAN Pemanfaatan Waktu Belajar Mengajar dalam KBM}

Sebagaimana ditentukan kurikulum 1994, jumlah jam pelajaran dalam satu minggu untuk keseluruhan mata pelajaran pada setiap kelas adalah 42 jam pelajaran. Pelajaran Bahasa Indonesia memperoleh alokasi waktu 6 jam pelajaran, dan setiap jam pelajaran selama 45 menit. Hasil observasi di lapangan menunjukkan bahwa pelaksanaan kegiatan belajar mengajar untuk mata pelajaran Bahasa 
Indonesia di SLTP belum memenuhi ketentuan alokasi waktu sesuai tuntutan GBPP kurikulum 1994. Rata-rata waktu yang efektif digunakan dalam KBM selama dua jam pelajaran rata-rata hanya 80 menit 28 detik, atau setiap jam pelajaran selama 40 menit 14 detik (ATT Actual). Ini berarti, setiap jam pelajaran yang tidak dipakai oleh guru adalah 4 menit 32 detik, karena jam pelajaran yang ditentukan (ATT Official) adalah 45 menit. Jadi total waktu yang digunakan untuk KBM mata pelajaran Bahasa Indonesia terpaut dan berkurang 4 menit
32 detik dari waktu yang ditentukan oleh kurikulum.

Berdasarkan observasi kelas, diketahui beberapa penyebab tidak dimanfaatkannya waktu KBM secara maksimal dikarenakan berbagai sebab. Terdapat separuh (50 persen) SLTP yang melakukan pengurangan waktu KBM dengan sengaja oleh sekolah. Hal itu diketahui dari jadwal kelas yang direncanakan oleh sekolah yang tidak menetapkan satu jam pelajaran selama 45 menit.

Tabel 1. Penyebab Waktu KBM tidak Dimanfaatkan secara Maksimal

\begin{tabular}{|c|l|c|c|c|}
\hline \multirow{2}{*}{ No. } & \multicolumn{1}{|c|}{ Penyebab } & \multicolumn{3}{|c|}{ Persentase } \\
\cline { 3 - 5 } & & Ya & Tdk. & Total \\
\hline 1 & Pengurangan waktu KBM oleh sekolah & 50,0 & 50,0 & 100,0 \\
\hline 2 & Persiapan kelas & 55,6 & 44,4 & 100,0 \\
\hline 3 & Guru terlambat masuk ke kelas & 44,4 & 55,6 & 100,0 \\
\hline 4 & KBM dipercepat lebih awal & 5,6 & 94,4 & 100,0 \\
\hline
\end{tabular}

Kelompok sekolah ini dengan sengaja menjadwalkannya dalam struktur jadwal kelas untuk semua mata pelajaran, termasuk mata pelajaran Bahasa Indonesia, rata-rata hanya mengalokasikan setiap jam pelajaran selama 40 menit. Dengan demikian, sekolah-sekolah tersebut merencanakan pengurangan waktu belajar secara transparan, dan sistimatis sebagai kegiatan resmi sekolah. Sekolah-sekolah yang mengalokasikan jam pelajaran di bawah ketentuan kurikulum, hampir semuanya terjadi pada sekolah yang diselenggarakan pada sore hari. Informasi dari kepala sekolah menunjukkan bahwa pengurangan waktu selama lima menit untuk setiap jam pelajaran tersebut antara lain ditujukan untuk menghindarkan siswa pulang ke rumah sampai malam hari. Dengan pengurangan waktu lima menit untuk 5 s/d 7 mata pelajaran setiap hari sekolah, maka kepulangan siswa menjadi lebih awal, 25 s/d 35 menit. Kecuali itu, percepatan waktu belajar dilakukan dengan pertimbangan situasi belajar sore dianggap kurang kondusif untuk KBM, misalnya siswa mudah mengantuk, dan cepat lelah. Untuk beberapa kasus, kebijakan sekolah sore ini menguntungkan bagi guru yang mengajar pada dua kesempatan, pagi dan sore hari. Percepatan waktu belajar akan mengurangi waktu tugas guru.

Di antara 18 sekolah yang diobservasi, ditemukan satu sekolah sore yang tidak melakukan pengurangan waktu belajar, atau tetap mengalokasikan waktu selama 45 menit per mata pelajaran. Sekolah ini berupaya konsisten dan taat mengalokasikan waktu sesuai ketentuan kurikulum. Sebaliknya, ditemukan satu sekolah negeri yang memiliki kelas pagi dan sore, tetapi 
memberlakukan waktu belajar 40 menit setiap jam pelajaran, baik untuk kelas pagi maupun kelas sore. Hal ini ditempuh dengan alasan agar siswa yang masuk sore dapat lebih awal menggunakan kelas, sehingga siswa dapat lebih awal mengakhiri kegiatan belajarnya dan tidak terlalu malam tiba di rumah.

Berkurangnya waktu KBM Bahasa Indonesia, terjadi juga karena guru $(44,4$ persen) terlambat datang di kelas. Keterlambatan guru hadir di kelas, seringkali terjadi dan tampaknya sulit untuk dihindari (Nursalim, 2011). Hal tersebut karena pada tingkat SLTP yang menerapkan sistem guru mata pelajaran atau guru bidang studi, pergantian jam pelajaran diikuti pula oleh pertukaran guru pada masing-masing kelas. Mobilitas pertukaran guru antarkelas tersebut membutuhkan waktu, meskipun hanya beberapa menit, dan dengan sendirinya akan mengurangi waktu KBM. Pertukaran guru antarkelas dapat menjadikan tersitanya waktu KBM. Lebih-lebih jika guru yang seharusnya habis waktu mengajar, ternyata masih menambah beberapa menit. Penambahan waktu ini terjadi misalnya untuk menuntaskan penjelasan atau mengumpulkan hasil tugas kelas. Hal seperti ini berakibat mengurangi waktu belajar untuk KBM guru berikutnya.

Kecuali itu, ditemukan beberapa kasus yakni guru kurang disiplin dalam waktu mengajar karena berbagai sebab: misalnya guru lupa jadwal mengajar, pergi ke WC terlalu lama, mampir di ruang guru untuk minum, ngobrol, atau mengambil bahan/peralatan mengajar yang tertinggal. Kegiatan semacam itu sering menyita waktu. Hilangnya waktu belajar di kelas dapat terjadi pula karena kegiatan-kegiatan yang dilakukan oleh guru untuk persiapan kelas. Persiapan kelas yang diperhitungkan dalam studi ini adalah kegiatan guru untuk mengabsen siswa, menghapus papan tulis, membagi buku tugas kepada siswa, menertibkan siswa, mengambil alat tulis, atau kegiatan lain sebelum memulai membahas materi pengajaran. Lebih dari separuh $(55,6$ persen) guru Bahasa Indonesia ditemukan kurang efektif dalam mengelola persiapan kelas tersebut, sehingga mengurangi alokasi waktu mengajar.

Mengacu pada rata-rata waktu yang dimanfaatkan oleh guru dalam KBM (ATT Actual), yakni selama 40 menit 14 detik setiap jam pelajaran atau 80 menit 28 detik untuk dua jam pelajaran. Disimak dari sisi penggunaan waktu setiap langkah pengajaran, diketahui bahwa pemanfaatan waktu oleh guru dalam KBM selama 2 jam pelajaran, ternyata lebih didominasi untuk kegiatan pemberian tugas kepada siswa, sebagaimana tampak pada tabel berikut.

Tabel 2. Pemanfaatan Waktu Belajar (2 Jam Pelajaran) Guru Bahasa Indonesia Tingkat SLTP Berdasarkan Tahapan Pengajaran

\begin{tabular}{|c|l|c|c|}
\hline No. & \multicolumn{1}{|c|}{ Jenis Kegiatan dalam KBM } & $\begin{array}{c}\text { Lama Kegiatan } \\
\text { (menit }: \text { detik) }\end{array}$ & $\begin{array}{c}\text { Persentase } \\
(\boldsymbol{\%})\end{array}$ \\
\hline 1 & Review (Tinjauan) & 5.07 & 6,3 \\
\hline 2 & Overview (Peninjauan luas) & 18.04 & 22,5 \\
\hline 3 & Penjelasan materi & 17.17 & 21,4 \\
\hline 4 & Tugas kelas dan Pembahasan PR & 40.00 & 49,8 \\
\hline \multicolumn{2}{r|}{ Jumlah } & $\mathbf{8 0 . 2 8}$ & $\mathbf{1 0 0 , 0}$ \\
\hline
\end{tabular}


Tabel 3 menunjukkan tahapan KBM di kelas, dimulai dari review, overview, penjelasan, dan penugasan dari guru kepada siswa. Terlihat bahwa selama KBM berlangsung, porsi waktu yang terbesar (49,8 persen) digunakan oleh guru untuk memberikan tugas kelas dan pembahasan pekerjaan rumah (PR) kepada siswa; yakni selama 40 menit untuk dua jam pelajaran, atau rata-rata 20 menit setiap jam pelajaran. Umumnya guru cenderung memberikan kegiatan kepada siswa untuk menyelesaikan tugas, berupa latihan menjawab soal-soal dari buku paket. Misalnya, menyusun surat pribadi, surat izin, mencari padanan kata, arti kata, atau menjawab pertanyaan dari suatu bacaan yang diambil dari buku paket. Ditemukan kesan guru lebih bergantung pada bahan pelajaran yang berasal dari buku paket, termasuk untuk latihan dan penugasan. Hanya sebagian guru saja yang memiliki kreativitas dan berinisiatif memberikan tugas dan latihan sesuai kondisi lingkungan sosial siswa.

Kecuali itu, seperlima waktu lainnya dialokasikan oleh guru untuk melakukan overview. Overview merupakan kegiatan untuk menjelaskan tujuan dan sasaran pembelajaran, termasuk manfaat dan kegunaan mempelajari materi yang akan diajarkan oleh guru. Diketahui, porsi waktu untuk kegiatan overview rata-rata 18 menit per dua jam pelajaran ( 9 menit per jam pelajaran), atau mencapai 22,5 persen dari seluruh waktu yang digunakan dalam KBM. Sebagian guru menggunakan waktu KBM untuk review, pada awal pelajaran dimulai. Review dimaksudkan untuk mengingatkan kembali siswa terhadap materi pelajaran yang lalu sehingga, akan memudahkan pembahasan materi berikutnya, sekaligus melihat pemahaman siswa terhadap pokok-pokok bahasan yang pernah diberikan oleh guru (Sitepu \& Rita, 2017). Alokasi waktu yang dipakai guru untuk review ini ratarata 5 menit tujuh detik, atau dalam satu jam pelajaran 2 menit 37 detik. Disimak dari persentasenya, kegiatan review diketahui menggunakan porsi 6,3 persen dari seluruh waktu efektif dalam KBM.

Penjelasan materi mata pelajaran, ternyata menyita waktu 21,4 persen dari seluruh waktu KBM. Selama dua jam pelajaran guru menjelaskan materi tersebut selama 17 menit 7 detik, atau dalam satu jam pelajaran rata-rata 8 menit 47 detik. Dibandingkan dengan porsi waktu untuk kegiatan penugasan dan latihan, porsi waktu untuk penjelasan materi tersebut jauh lebih kecil; waktu untuk penugasan/latihan adalah 49,8 persen, sedangkan penjelasan materi 21,4 persen dari seluruh waktu yang digunakan dalam KBM. Sebagian guru memang sengaja lebih banyak memberikan porsi latihan praktis. Namun demikian, ditemukan kesan pada beberapa guru bahwa banyaknya porsi latihan tersebut disebabkan guru kurang memiliki bahan untuk memperluas dan memperdalam materi yang dapat dijelaskan pada sesi penjelasan. Oleh sebab itu, pada saat latihan tersebut ditemukan beberapa guru yang beristirahat, sambil menunggu hasil tugas dari siswa.

Sebagaimana dipahami, materi kurikulum yang dituangkan dalam GBPP memuat program, isi/materi belajar, dan alokasi waktu per catur wulan untuk setiap jenjang kelas (Rofatayatun \& Afifurrahman, 2019). Berdasarkan pendapat guru, diketahui bahwa sebagian 
besar guru menilai bahwa alokasi waktu dan materi belajar pada mata pelajaran Bahasa Indonesia dalam GBPP, sudah cukup memadai. Artinya dengan waktu yang disediakan, materi belajar dapat disampaikan secara wajar, dan tidak mengalami kekurangan waktu. Hampir semua guru menilai bahwa materi pelajaran Bahasa Indonesia yang diprogramkan tersebut tidak terlalu banyak, sehingga tidak kekurangan waktu. Meskipun demikian, di antara para guru (22,2 persen) tersebut mengemukakan bahwa alokasi waktu yang tercantum pada GBPP masih kurang, sehingga perlu ditambah lagi alokasi waktunya. Tidak ditemukan informasi dari guru yang berpendapat bahwa alokasi waktu dalam GBPP tersebut berlebih.

Tabel 3. Penilaian Guru Bahasa Indonesia terhadap Alokasi Waktu yang Disediakan dalam GBPP

\begin{tabular}{|c|l|c|}
\hline No. & \multicolumn{1}{|c|}{ Ketercukupan Waktu } & Persentase \\
\hline 1 & Cukup terpenuhi & 38,9 \\
\hline 2 & Cukup tetapi kurang untuk pendalaman & 33,3 \\
\hline 3 & Kekurangan & 22,2 \\
\hline 4 & Kelebihan & 0,0 \\
\hline 5 & Lainnya Jumlah & 5,6 \\
\hline \multicolumn{2}{|c|}{} \\
\hline
\end{tabular}

Tabel 4 menunjukkan sebagian besar guru menyatakan bahwa alokasi waktu yang disediakan dalam GBPP adalah cukup, dalam arti tidak mengalami kelebihan dan kekurangan waktu belajar. Mereka yang menganggap cukup tersebut 38,9 persen di antaranya dengan tegas menyatakan cukup terpenuhi; sedangkan 33,3 persen guru lainnya menilai cukup namun, dengan catatan waktu yang disediakan tersebut masih dinilai kurang jika diperlukan untuk kegiatan pendalaman materi. Jika menyimak hasil observasi tentang tahapan penggunaan waktu belajar (tabel 3), dengan jelas ditunjukkan bahwa persentase terbesar (49,8 persen) KBM digunakan guru untuk pemberian tugas, yakni rata-rata 20 menit setiap jam pelajaran berlangsung. Oleh sebab itu, pengakuan guru terhadap kurangnya alokasi waktu tersebut patut disimak lagi kebenarannya; barangkali bukan karena waktunya kurang melainkan pengelolaan waktu mengajar yang belum dilakukannya secara optimal. Pemahaman dan Penguasaan Guru Perencanaan Mengajar

Salah satu aspek penting dalam adalah keberadaan dan kualitas perencanaan mengajar. Mutu persiapan mengajar antara lain ditentukan oleh kelengkapan dokumen kurikulum dan kualitas penjabaran kurikulum/GBPP oleh guru (Lubis, 2015). Kelengkapan persiapan mengajar dapat dikaji dari keberadaan Program Tahunan, Program Catur Wulan, Satuan Pelajaran, dan kelengkapan lain seperti Perencanaan Kegiatan Harian dan Analisis Mata Pelajaran. Dalam persiapan mengajar, disimak pula buku dan alat peraga yang digunakan guru dalam mengajar. Berdasarkan kriteria tersebut diketahui bahwa guru Bahasa Indonesia di SLTP hampir semuanya (94,5 persen) telah berusaha mengadakan persiapan mengajar. Dari 18 sekolah yang diamati, 
diketahui hanya terdapat satu guru saja yang sama sekali tidak memiliki perencanaan mengajar. Guru yang tidak memiliki perencanaan tersebut hanya mengandalkan KBM dari buku paket.

Dari sejumlah guru yang memiliki perencanaan mengajar, 44,4 persen di antaranya memiliki persiapan yang masuk dalam kategori cukup. Sedangkan, guru yang dinilai memiliki persiapan mengajar dengan kategori baik, ada 38,9 persen. Dari observasi diketahui bahwa hampir semua guru Bahasa Indonesia telah memiliki perencanaan mengajar, namun sebagian besar masih belum memiliki kelengkapan dan mutu perencanaan yang baik.

Tabel 4. Aspek pemahaman dan Penguasaan Guru terhadap Materi Pelajaran dalam KBM Bahasa Indonesia di SLTP

\begin{tabular}{|c|c|c|c|c|c|}
\hline \multirow{2}{*}{ No } & \multirow{2}{*}{$\begin{array}{c}\text { Aspek Pemahaman dan } \\
\text { Penguasaan Materi Belajar }\end{array}$} & \multicolumn{3}{|c|}{ Ada Dengan Kualitas } & \multirow{2}{*}{$\begin{array}{c}\text { Tidak } \\
\text { Ada }\end{array}$} \\
\hline & & Kurang & Cukup & Baik & \\
\hline 1 & Persiapan/ Perencanaan Mengajar & 0,0 & 44,4 & 38,9 & 5,5 \\
\hline 2 & $\begin{array}{l}\text { Menyatakan eksplisit atau implisit } \\
\text { tujuan pembelajaran }\end{array}$ & 0,0 & 11,1 & 50,0 & 38,9 \\
\hline 3 & $\begin{array}{l}\text { Mereview materi pelajaran } \\
\text { sebelumnya }\end{array}$ & 0,0 & 22,2 & 27,8 & 50,0 \\
\hline 4 & $\begin{array}{l}\text { Menjelaskan kegunaan materi } \\
\text { yang akan dipelajari }\end{array}$ & 16,7 & 27,8 & 11,1 & 44,4 \\
\hline 5 & $\begin{array}{l}\text { Mendorong/memotivasi siswa } \\
\text { belajar lebih baik }\end{array}$ & 0,0 & 77,8 & 16,7 & 5,5 \\
\hline 6 & $\begin{array}{l}\text { Materi yang dibahas sesuai } \\
\text { dengan kurikulum }\end{array}$ & 22,2 & 22,2 & 55,6 & 0,0 \\
\hline 7 & $\begin{array}{l}\text { Pembahasan komprehensif dan } \\
\text { mendukung tujuan pembelajaran }\end{array}$ & 5,5 & 33,4 & 27,8 & 33,4 \\
\hline 8 & $\begin{array}{l}\text { Fakta, konsep dan definisi } \\
\text { diutarakan secara tepat dan utuh }\end{array}$ & 22,2 & 50,0 & 11,1 & 16,7 \\
\hline 9 & $\begin{array}{l}\text { Pengenalan konsep diikuti contoh } \\
\text { dan kesimpulan yang tepat }\end{array}$ & 11,1 & 55,5 & 33,4 & 0,0 \\
\hline 10 & $\begin{array}{l}\text { Latihan/tes yang diberikan } \\
\text { mengkaitkan tema, situasi dan } \\
\text { skill dengan topik bahasan }\end{array}$ & 22,2 & 50,0 & 27,8 & 0,0 \\
\hline
\end{tabular}

\section{Pelaksanaan KBM}

Umumnya setiap KBM di kelas diawali dengan review terhadap pelajaran yang telah diberikan guru. Review saat awal pelajaran, berfungsi untuk mengingatkan kembali kepada siswa terhadap materi pelajaran yang lalu agar terjadi kelancaran proses dalam pembahasan materi lanjutan (Nursalim, 2011). Hasil pengamatan kelas menunjukkan bahwa separuh dari guru Bahasa Indonesia (50,0 persen) ternyata sama sekali tidak melakukan review. Para guru langsung masuk dalam pembahasan materi inti, tanpa mengingatkan kembali siswa tentang pelajaran yang diberikan sebelumnya. Ini menunjukkan bahwa guru belum menyadari pentingnya sebuah review. Memang tidak semua KBM senantiasa diawali dengan review, yakni jika materi yang akan dibahas merupakan pokok bahasan/subpokok bahasan yang lepas dan tidak berhubungan dengan materi pelajaran yang diajarkan guru 
sebelumnya. Tetapi, para guru memang melupakan tahap tersebut, karena hampir semua pembahasan umumnya berkaitan dengan materi pelajaran sebelumnya. Sebaliknya, terdapat separuh guru $(50,0$ persen) tampak menempuh prosedur review. Kendati menempuh prosedur review namun, tidak semuanya tampak melakukannya dengan baik. Hanya 27,0 persen saja guru yang melakukannya dengan baik dalam menyampaikan proses review tersebut; dan 22,8 persen dengan cara secukupnya saja.

Misalnya, hanya sedikit guru yang menyinggung pelajaran lalu tanpa menyimak apakah siswa telah memahaminya. Data ini menunjukkan bahwa hanya sebagian guru saja yang melakukan prosedur review dengan baik. Bahkan masih banyak guru yang tidak melakukannya; sehingga berpotensi sering terjadi diskontinuitas (tidak menyambung) antara pembahasan materi sebelumnya dengan materi yang sedang disampaikan dalam KBM

Selain review, penjelasan guru tentang tujuan mempelajari materi pelajaran adalah penting dalam KBM, yakni dapat memotivasi siswa memahami materi yang diajarkan (Fakhrurrazi, 2018). Dalam konteks ini diketahui terdapat separuh responden (50,0 persen) guru yang menyampaikan tujuan membahas materi pelajaran dengan kategori baik. Dalam arti guru tersebut telah berusaha untuk menyampaikan tujuan dengan rumusan dan cara penyampaian yang meyakinkan, sehingga berpotensi meningkatkan motivasi belajar siswa. Guru yang lain (11,1 persen) juga telah melakukannya, namun penyampaiannya belum begitu meyakinkan. Ditemukan data yang agak memprihatinkan, yakni terdapat 38,9 persen guru yang sama sekali tidak menyampaikan tujuan KBM. Dengan kata lain, guru tersebut sama sekali tidak mengutarakan kompetensi apa yang harus dimiliki oleh siswa jika menguasai materi yang akan dipelajarinya. Kecuali itu, hampir separuh $(44,4$ persen) guru juga tidak menyampaikan sama sekali apa kegunaan mempelajari materi pelajaran tersebut. Hal ini sedikit banyak akan mengurangi motivasi siswa dalam belajar dan tidak dipahaminya secara jelas apa siswa mempelajari materi pelajaran tersebut.

Meskipun hampir semua guru menyusun perencanaan belajar sesuai dengan kurikulum, ternyata hal itu tidak sepenuhnya diwujudkan dalam praktik mengajar di kelas. Indikasi ini diketahui dari pengamatan di lapangan, ditemukan hampir seperempat responden guru $(22,2$ persen) menyampaikan materi pelajaran kurang sesuai dengan GBPP kurikulum 1994 (meskipun para guru umumnya telah mempersiapkan program pengajaran). Kurang sesuainya pelaksanaan pengajaran dengan GBPP melalui beberapa indikasi, misalnya penjelasan materi pelajaran tidak dikaitkan dengan tema pengajaran yang telah ditentukan dalam GBPP; atau sebaliknya ada guru yang justru membahas tema menyangkut pengertian dan pendalaman, serta guru lupa terhadap sub pokok bahasan dan tujuan pembelajaran tentang suatu aspek pengajaran Bahasa Indonesia tertentu. Indikasi lain dapat ditangkap dari aspek tujuan pembelajaran; yakni guru kurang menampakkan upaya untuk mencapai salah satu atau beberapa tujuan penting belajar Bahasa Indonesia pada umumnya, 
antara lain mendapatkan pemahaman, sikap, dan keterampilan dalam menyimak, membaca, menulis, mengaplikasikan, dan mampu menganalisis suatu aspek kebahasaan tertentu.

Sejumlah guru sering menyandarkan pembahasan materi belajar hanya dengan buku paket, padahal belum tentu setiap buku yang digunakan benar-benar menunjang kurikulum yang ditentukan. Baik disimak dari segi isi materi belajar, maupun alokasi waktu yang ditentukan dalam kurikulum. Bahkan sering terjadi buku paket tersebut kurang sesuai dengan kondisi dan situasi sosial siswa. Dengan informasi tersebut dapat dipahami bahwa ternyata ada sejumlah guru dalam melaksanakan KBM belum membahas materi pelajaran sesuai dengan tuntutan kurikulum. Namun demikian, sebagian besar guru telah sesuai dalam menyampaikan materi belajar KBM, baik dibandingkan dengan program perencanaan yang mereka susun, maupun dengan GBPP secara keseluruhan. Ada 50 persen guru yang secara baik menyampaikan materi belajar sesuai dengan program yang mereka susun, dan 11,1 persen lainnya cukup sesuai dengan program perencanaan mengajar dan kesesuaiannya dengan kurikulum.

Dalam pembahasan materi pelajaran masih ditemukan 33,4 persen guru belum mengkaji materi secara komprehensip sehingga, apa yang dibahas tidak serta merta mendukung tujuan pempelajaran. Namun selebihnya, guru telah berupaya untuk menyampaikan materi dengan berbagai cara untuk mendukung tujuan pembelajaran; 27,8 persen di antara guru dinilai secara baik telah melakukannya, 33,4 persen guru yang lain melakukan hal tersebut namun belum menunjukkan kinerja yang maksimal, bahkan ada 5,5 persen guru yang dinilai kurang malakukannya dengan baik. Informasi ini memberikan indikasi bahwa sebagian besar guru dalam mengajar Bahasa Indonesia belum dapat mengkaji secara komprehensip. Artinya, secara proporsional dalam pengkajiannya selalu mengkaitkan dengan tema yang ditetapkan dalam GBPP, berusaha untuk memberikan definisi contoh ataupun padanan yang sesuai dengan tingkat usia siswa serta lingkungan sosialnya, dan secara terpadu dapat memberikan pemahaman, keterampilan menyimak, membaca, menulis/mengarang, dan mencoba untuk mengaplikasikannya. Dari sampel guru yang diobservasi, diketahui bahwa mereka yang dapat mengkaji pokok bahasan/sub pokok bahasan pelajaran Bahasa Indonesia kelas II SLTP, secara terpadu dan menyeluruh serta proporsional jumlahnya terbatas. Umumnya para guru mencari kemudahan mengajar, antara lain dengan membahas materi yang disediakan dalam buku paket, sekaligus bahan-bahan latihan, tanpa berusaha secara kreatif untuk mencari bahan atau contoh dan padanan lain yang mudah dipahami dan menarik siswa untuk mencapai tujuan pembelajaran secara baik.

Dalam hal pendefinisian, sebagian besar guru telah berupaya melakukan namun, belum mencapai hasil yang meyakinkan. Ditemukan 50,0 persen guru mencoba mendefinisikan setiap konsep dan fakta namun baru mencapai taraf yang cukup dalam arti sudah mengarah pada cara yang tepat dan menyeluruh 
walaupun belum maksimal. Sedangkan, guru yang masih kurang tepat dalam penyampaian atau pendefinisian tersebut ada 22,2 persen. Guru yang relatif baik dalam menyampaikan definisi setiap konsep dan fakta dengan cara yang utuh dan menyeluruh untuk materi yang dibahasnya persentasenya tergolong rendah, yakni hanya 11,1 persen.

Untuk memudahkan pemahaman menyangkut konsep tertentu, selain mengemukakan definisi terhadap pengertian konsep, juga pemberian contoh-contoh yang dekat dengan kehidupan siswa maupun hal-hal yang actual (Ulfa \& Saifuddin, 2018). Dalam observasi diketahui bahwa semua guru telah memberikan contoh-contoh tertentu dalam rangka memudahkan pemahaman siswa terhadap suatu materi tertentu. Namun, baru 27,8 persen guru yang tampak telah mengambil contoh-contoh yang tepat dan relevan; selebihnya 50 persen guru mengambil contoh dengan ketepatan dan relevansi yang sedang/cukup. Bahkan ditemukan 22,2 persen guru yang mengambil contoh kurang tepat/relevan dengan materi yang sedang dibahas.

Guru Bahasa Indonesia memberikan porsi yang cukup besar pada latihan/penugasan kepada siswa (Nurjanna, 2015); (Prihatin, 2020). Kecenderungan ini bisa dinilai sebagai gejala yang baik, namun sebaliknya dapat merupakan gejala yang kurang baik. Latihan dan tugas akan baik jika materi yang dibahas memerlukan latihan-latihan agar siswa memiliki keterampilan berbahasa, menulis, atau menyimak, dan menganalisis materi tertentu. Gejala kurang baik bisa terjadi manakala latihan dalam porsi yang besar diterapkan untuk mengurangi alokasi waktu guru dalam memberikan dasar-dasar pemahaman pada setiap materi yang dibahas, dan guru memang menghindar dari penyampaian materi tertentu, atau cenderung malas mengajar. Lepas dari kecenderungan itu, dalam hal tugas/latihan semua guru selalu memberikan latihan/tugas kepada siswa; dengan variasi mutu yang beragam. 22,2 persen guru memberikan tugas/latihan yang kurang bermutu, karena tidak mengkaitkan pekerjaan siswa tersebut dengan tema yang sedang dipelajari, atau kurang sesuai dengan kondisi dan keterampilan siswa. Terdapat 50 persen guru yang telah berupaya selalu mengkaitkan materi latihan dengan kemampuan dan keterampilan siswa serta tema yang sedang dibahas dengan taraf sedang; artinya guru sudah berupaya memberikan tugas yang relevan, meskipun belum dilakukan dengan mutu yang baik. Sedangkan kegiatan penugasan yang dinilai bermutu baik ada 27,8 persen.

\section{Metodologi Mengajar}

Umumnya pendekatan belajar mengajar guru Bahasa Indonesia belum menampakkan pilihan-pilihan metode sesuai dengan tingkat usia siswa, pokok bahasan/sub bahasan yang dikaji, prosedur pengajaran, dan kondisi kelas yang baik. Masih sedikit guru yang berupaya mencari pendekatan belajar mengajar secara meyakinkan, antara lain dapat menarik dan memotivasi siswa belajar terhadap materi yang diajarkan. Akibatnya, KBM yang dilaksanakan belum sepenuhnya mencapai tujuan pengajaran

Sebagian besar guru masih menggunakan komunikasi searah, dari guru kepada siswa. Pendekatan KBM yang searah mengakibatkan tiadanya 
kesempatan siswa untuk belajar keterampilan berbahasa, mengemukakan gagasan, serta mewujudkan kreativitasnya (Hidayah, 2014). Meskipun demikian, ditemukan beberapa guru telah mencoba mengembangkan pendekatan mengajar dengan baik, yakni memberikan pemahaman dan keterampilan berbahasa dengan memberikan kesempatan kepada siswa untuk mengemukakan pendapatnya, berusaha mengajarkan secara kontekstual, dan mengaplikasikannya dalam praktik; pembahasan materi tetap berpegang pada pengembangan keterampilan siswa untuk menyimak, membaca, dan menulis/mengarang, bahkan mengaplikasikannya dalam kehidupan sosial siswa dengan berbagai cara.

Hal lain yang perlu dicatat dari observasi kelas adalah belum banyak guru yang memperhatikan pengorganisasian kelas dengan baik yang sesuai dengan situasi dan kondisi lingkungan kelas, siswa, dan materi yang sedang dibahas. Ketertiban dan disiplin kelas masih belum diperhatikan secara baik, siswa yang pasif kurang diberi dorongan untuk aktif terlibat dalam $\mathrm{KBM}$, sistem latihan dan penugasan juga belum dikontrol melalui pemantauan yang terencana, sehingga tahap latihan sering dipakai siswa untuk istirahat, mengobrol, dan tindakan lain yang mengganggu KBM.

Tabel 5. Penguasaan Guru Terhadap Metodologi Mengajar dalam KBM Bahasa Indonesia di SLTP

\begin{tabular}{|c|c|c|c|c|c|}
\hline \multirow[b]{2}{*}{ No } & \multirow{2}{*}{$\begin{array}{c}\text { Aspek Pemahaman dan } \\
\text { Penguasaan Guru terhadap } \\
\text { Metodologi Mengajar }\end{array}$} & \multicolumn{3}{|c|}{ Ada Dengan Kualitas } & \multirow{2}{*}{ Tidak } \\
\hline & & Kurang & Cukup & Baik & \\
\hline 1 & $\begin{array}{l}\text { Penyajian materi dari tidak } \\
\text { dikenal menjadi dikenal }\end{array}$ & 0,0 & 66,7 & 33,3 & 0,0 \\
\hline 2 & $\begin{array}{l}\text { Penyajian materi dari sederhana } \\
\text { ke kompleks }\end{array}$ & 5,5 & 66,7 & 27,8 & 0,0 \\
\hline 3 & $\begin{array}{l}\text { Penyajian materi dari mudah ke } \\
\text { sulit }\end{array}$ & 11,1 & 55,6 & 33,3 & 0,0 \\
\hline 4 & $\begin{array}{l}\text { Penyajian materi dari kongkrit ke } \\
\text { abstrak }\end{array}$ & 16,7 & 44,4 & 5,5 & 27,8 \\
\hline 5 & $\begin{array}{l}\text { Menggunakan bahasa/ } \\
\text { perbendaharaan konsep } \\
\text { dengan kondisiah, } \\
\text { deswai }\end{array}$ & 5,5 & 55,6 & 38,9 & 0,0 \\
\hline 6 & $\begin{array}{l}\text { Memakai kalimat pendek dan } \\
\text { sederhana }\end{array}$ & 0,0 & 66,7 & 33,3 & 0,0 \\
\hline 7 & Menggunakan alat bantu & 0,0 & 0,0 & 0,0 & 100,0 \\
\hline
\end{tabular}

Dalam konteks proses pengajaran, guru diharapkan menempuh prosedur penyampaian materi pelajaran dari tahap tidak dikenal, sederhana, kongkrit, dan mudah menuju ke tahap menjadi dikenal, lebih kompleks, dan sulit, sehingga siswa secara bertahap pula memahami materi pelajaran dengan lancar dan tuntas
(Nurrita, 2018). Umumnya guru yang diobservasi belum sepenuhnya menempuh tahap-tahap pembelajaran tersebut; dan mereka yang mencoba mengikuti alur pengajaran tersebut jumlahnya belum begitu meyakinkan. Hal itu tampak misalnya, pada tahapan penyajian materi belajar yang paling 
awal, yakni menyajikan materi yang sebelumnya tidak dikenal menjadi dikenal oleh siswa, belum semua guru menyampaikannya dengan baik. Hanya 33,3 persen guru yang dinilai telah menempuh penyajian materi dari tidak dikenal menjadi dikenal dalam taraf yang baik; sedangkan guru lainnya $(66,7$ persen) masih pada taraf yang cukup. Hal senada juga terjadi pada penyajian materi dari sederhana menuju ke komleks, guru yang berada dalam penilaian "cukup" ada 66,7 persen, dan yang telah berada pada penyajian yang baik ada 27,8 persen; dan dalam penyajian ini justru ditemukan 5,5 persen guru yang menyampaikannya kurang baik.

Dalam perspektif lain, 11,1 persen guru yang kurang memperhatikan penyajian materi dari mudah ke sulit; atau mereka langsung membahas hal-hal yang sulit tanpa diawali pengertian yang lebih mudah. Sedangkan guru yang menyajikan dari mudah ke sulit dengan kategori cukup ada 55,6 persen, serta mereka yang relatif menempuh prosedur dengan baik" mencapai 33,3 persen guru. Jarang guru yang berusaha untuk menjelaskan materi pelajaran dari kongkrit ke abstrak. Bahkan guru yang sama sekali tidak melalui prosedur tersebut persentasenya cukup besar, yakni mencapai 27,8 persen. Guru yang mencoba menyajikan tahapan itu, tetapi disajikan dengan kurang baik ada 44,4 persen guru. Guru yang dinilai telah dapat menjelaskan materi dari kongkrit menuju ke abstrak dengan "baik" hanya ada 5,5 persen guru.

Sepertiga responden guru yang dinilai telah menggunakan kalimat dan bahasa, serta perbendaharaan konsep sesuai dengan kondisi siswa (38,9 persen), demikian pula ada 33,3 persen yang relatif efisien menggunakan kalimat, yakni dengan pilihan kata pendek dan sederhana sehingga mudah dimengerti para siswa (33,3 persen). Lebih dari separuh responden dinilai dalam taraf yang cukup, yakni dalam menggunakan istilah, kalimat, bahasa untuk membahas dan mendefinisikan konsep sesuai dengan usia siswa. Hanya ada 5,5 persen guru yang pemilihan kata, istilah, dan kalimat yang sama sekali kurang mempedulikan tingkat usia siswa dan konsep yang ingin dijelaskan.

Hal yang agak memprihatinkan dalam KBM Bahasa Indonesia ini adalah tidak satupun KBM yang menggunakan alat bantu mengajar. Sedangkan alat bantu mengajar ini besar manfaatnya bagi siswa dan guru, antara lain membantu kelancaran pengajaran, memudahkan siswa menangkap pelajaran, memberikan visualisasi dan gambaran kongkrit terhadap materi yang dibahas, dari sisi lain dapat mendorong minat belajar, karena terdapat variasi penyajian. Dalam perencanaan mengajar, beberapa guru menetapkan alat peraga yang akan dipakai dalam KBM. Tetapi dalam praktik KBM tidak satupun guru yang menggunakan alat tersebut. Misalnya dalam pembahasan ceritera prosa, pada tahap perencanaan dicanangkan akan menggunakan radio kaset untuk mendengarkan ceritera tertentu, tetapi dalam KBM tidak dilakukan. Mengenai ketiadaan alat peraga dalam KBM tersebut, bukanlah semata-mata kesalahan guru. Hasil wawancara kepada guru, diperoleh informasi bahwa permintaan jenis alat peraga yang dibutuhkan dalam KBM tidak selalu dapat dipenuhi oleh sekolah karena keterbatasan dana.

\section{KESIMPULAN}

Dari uraian dan analisis studi, dapat disimpulkan bahwa Guru Bahasa Indonesia tingkat SLTP ternyata belum 
memanfaatkan alokasi waktu belajar secara maksimal. Ketentuan GBPP (ATT Official) selama 45 menit setiap jam pelajaran, dalam implementasinya (ATT Actual) ternyata hanya diimplementasikan selama 40 menit 14 detik. Waktu belajar juga belum dikelola secara proporsional dalam KBM. Porsi terbesar digunakan oleh guru untuk penugasan/latihan, dibanding untuk penjelasan materi, review, overview, dan evaluasi belajar. Di samping itu, baru beberapa guru yang diketahui telah memiliki kemampuan yang cukup baik dalam merencanakan KBM, memilih metodologi mengajar, dan mengorganisasi kelas, sehingga tujuan pembelajaran belum mencapai taraf yang optimal. Berdasarkan kesimpulan studi, direkomendasikan beberapa kebijakan sebagai berikut.

Pertama, alokasi waktu belajar yang ditetapkan dalam kurikulum perlu dikelola dengan tertib dan proporsional. Sekolah yang diselenggarakan sore hari perlu mengatur jadwal pelajaran, tanpa mengurangi alokasi waktu yang telah ditentukan, agar guru dapat membahas materi dan pendalaman secara memadai. Jika terpaksa mengurangi alokasi waktu, diharapkan sekolah tersebut dapat menempuh kebijakan menambah waktu belajar pada kesempatan tertentu, agar materi yang diperoleh siswa dapat sebanding dengan siswa yang belajar pagi hari. Dalam jangka panjang dapat direncanakan agar semua siswa dapat belajar pada pagi hari, dengan konsekuensi sekolah memperluas/membangun kelas-kelas baru; sehingga ketentuan alokasi waktu belajar (ATT Official) satu jam pelajaran selama 45 menit dapat dilaksanakan; tanpa kawatir siswa pulang malam.

Kedua, hendaknya guru dapat merencanakan KBM dan mendistribusikan waktu KBM dengan baik dan proporsional dalam tahapan review, overview, penjelasan materi, latihan, dan evaluasi belajar. Dengan cara tersebut, kecenderungan guru untuk lebih banyak memberikan tugas/latihan kepada siswa dan hanya selintas memberikan penjelasan materi dapat dihindarkan.ujuan belajar, manfaat dan kegunaan mempelajari topik tertentu perlu dirumuskan serta diungkapkan secara jelas dalam KBM sehingga dapat lebih mendorong motivasi siswa/antusias mempelajari materi belajar. Berkenaan dengan itu, rumusan GBPP kurikulum hendaknya memberikan gambaran/rumusan yang jelas tentang berbagai kompetensi yang perlu dikuasai siswa untuk setiap tahapan belajar, sehingga memudahkan guru untuk mengoperasionalkan tujuan/kompetensi dalam setiap tujuan pembelajaran.

Dalam upaya meningkatkan kemampuan dan penguasaan guru menyangkut perencanaan dan pelaksanaan KBM, perlu dilakukan langkah-langkah yang konsisten dan serius agar kinerja guru lebih bermutu. Seiring dengan kebijakan otonomi pendidikan, hendaknya pemerintah daerah memprioritaskan kegiatan pelatihan guru khususnya dalam memahami dan mengimplementasikan kurikulum, strategi mengajar, penguasaan materi; dan cara mengevaluasi belajar; bekerjasama dengan instansi terkait untuk menyelesaiakan masalah guru. Dalam konteks tersebut, wadah MGMP (Musyrawarah Guru Bidang Studi) dapat lebih diberdayakan sebagai wadah untuk meningkatkan profesi dan kinerja guru. 


\section{REFERENSI}

Afifurrahman, A., \& Rofayatun, R. (2019). Prodi Pendidikan Agama Islam dan Manajemen Pendidikan Islam Universitas Nurul Jadid Paiton Probolinggoo. TaLimuna: Jurnal Pendidikan Islam, 8(2), 24-36.

Darwin, I. O., Harun, M., \& Armia, A. (2018). Ragam Bahasa Guru Dalam Interaksi Kelas di Taman KanakKanak Islam Terpadu Ar-Rahmah Kota Banda Aceh. JIM Pendididikan Bahasa dan Sastra Indonesia,3(2), 143-153.

Devianty, R. (2017). Bahasa sebagai cermin kebudayaan. Jurnal tarbiyah, 24(2).

Fakhrurrazi, F. (2018). Hakikat Pembelajaran yang Efektif. At-Tafkir, 11(1), 85.

Filtri, H., \& Efastri, S. M. (2019). Komunikasi Pendidik Paud terhadap Perkembangan Bahasa Anak Usia Dini Sekecamatan Rumbai. PAUD Lectura: Jurnal Pendidikan Anak Usia Dini, 2(02), 102-110.

Hidayah, N. (2014). Pendekatan Pembelajaran Bahasa Whole Language. Jurnal Terampil, 3(3).

Lubis, A.Y., (2015). Pelaksanaan Manajemen Kurikulum Pada SMA Negeri 1 Buengcala Kabupaten Aceh Besar. Jurnal Administrasi Pendidikan, Vol. 3 (1), 13-33.

Mirna, W. (2020). Karakteristik Bahasa Guru Dalam Interaksi Belajar Mengajar Bahasa Indonesia di Kelas XXII MIPA 2 SMAN 1 Bangil Kabupaten Pasuruan. Lingue: Bahasa, Budaya, dan Sastra, 1(1), 54-67.

Nurjanna, N. (2015). Penggunaan Metode Pemberian Tugas Untuk Meningkatkan Keterampilan Menulis Surat Siswa Kelas IV SDN 2 Lais. Jurnal Kreatif Tadulako, 4(8).

Nurrita, T. (2018). Pengembangan Media Pembelajaran untuk Meningkatkan Hasil Belajar Siswa. Jurnal Misykat, 3(1),

171-187. doi:10.33511/misykat.v3i1.52.

Nursalim. (2011). Implementasi Kurikulum Bahasa Indonesia antara Harapan dan Kenyataan. Jurnal Sosial Budaya, 8(2), 250-266.

Prihatin, Y. (2020). Penanaman Budaya Membaca Dongeng Melalui Rumah Pintar di Desa Marmoyo. Jurnal Terapan Abdimas, 5(2), 186-191.

Setiawati, R. D. Variasi Bahasa Dalam Situasi Tidak Formal Pada Mahasiswa Program Studi Pendidikan Bahasa Indonesia di Universitas Tadulako. Bahasa dan Sastra, 4(1).

Sitepu, T., Rita. (2017). Bahasa Indonesia sebagai Media Primer Komunikasi Pembelajaran. Jurnal Pendidikan Bahasa dan Sastra Indonesia, 2(1), 67-73.

Situmorang, T. (2019). Kepribadian Guru Dalam Dunia Pendidikan. $A l$ Irsyad, 6(1).

Suhendar, N. (2016). Ragam Bahasa di Kecamatan Pakisjaya Kabupaten Karawang (Kajian Sosiolinguistik). Lokabasa, 7(1), 5361.

Ulfa, M. \& Saifuddin. (2018). Terampil Memilih dan Menggunakan Metode Pembelajaran. SUHUF. 30(1), 35-56.

Wardhani, K., Sailan, Z., Tanduklangi, A., \& Badara, A. (2019). Penggunaan Ragam Bahasa Melalui Whatsapp Kalangan Mahasiswa Pascasarjana Pendidikan Bahasa dan Sastra Indonesia Universitas Halu Oleo (Suatu Kajian Sosiolinguistik). Jurnal Pendidikan Bahasa, 8(1), 44-49. 